\title{
An investigation on effective factors influencing employee performance: A case study
}

\author{
Hamid Reza Alavi*, Farshid Abdi, Mohammad Mazuchi, Mohammad Kazem Bighami, and Atefe \\ Heidari
}

Industrial Engineering Department, South Tehran Branch, Islamic Azad University, Tehran, Iran

\begin{tabular}{|c|c|}
\hline CHRON I C LE & AB S TRACT \\
\hline $\begin{array}{l}\text { Article history: } \\
\text { Received January 10, } 2013 \\
\text { Received in revised format } \\
23 \text { April } 2013 \\
\text { Accepted } 29 \text { April } 2013 \\
\text { Available online } \\
\text { May } 12013 \\
\text { Keywords: } \\
\text { Performance appraisal } \\
\text { Employee productivity } \\
\text { Path analysis }\end{array}$ & $\begin{array}{l}\text { Human resources are considered as one of the key components of any organization to reach its } \\
\text { objectives. Human resources help organization performance doing organizational duties and } \\
\text { making employees' improvement. Because of this, employee performance appraisal has } \\
\text { changed to one of the most important issues for top managers. Performance appraisal is } \\
\text { necessary to select useful strategies for increasing productivity of human resource management } \\
\text { along with productivity of employee to get strategic targets. In this study, we extract effective } \\
\text { factors on increasing of employee performance and subsequently, present some suggestions to } \\
\text { managers of academic organizations. The study was performed on some employees who } \\
\text { worked for Islamic Azad University in 2012. Cronbach alpha was equal to } 99.4 \% \text { for employee } \\
\text { performance appraisal, which confirmed the overall survey. To recognize key factors we used } \\
\text { path analysis technique too. The results of the study revealed that in this school, employee } \\
\text { performance in practical field was higher than expected, but in terms of operational and } \\
\text { behavioral fields, they were in the middle stage. }\end{array}$ \\
\hline
\end{tabular}

(c) 2013 Growing Science Ltd. All rights reserved.

\section{Introduction}

Human resources are considered as one of the key components of any organization to reach its objectives. Human resources help organization performance doing organizational duties and making employees' improvement (Levinson et al., 1972). According to Mozaffari et al. (2012), the success of any firm depends on the quality of its management and management quality, in turn, depends on decision quality and information quality on the quality of its measurement and proportion. They presented a model for strategic planning of Islamic Azad university of Semnan. Mozaffari et al. (2013) presented a new framework for performance evaluation system using strategy map. Kohneh et al. (2013) implemented a hybrid of analytical hierarchy process along with balanced score card to measure the performance of five different civil registry offices in Tehran, Iran. They also used fuzzy terms to handle uncertainty in input numbers and using some technique convert fuzzy numbers into crisp values. Danaei

\footnotetext{
*Corresponding author.

E-mail addresses: alavi_hamidreza@yahoo.com (H. R. Alavi) 
and Hosseini (2013) investigated the existing strategic objectives in the strategy map of a pipe company located in city of Shiraz, Iran.

In recent decades, there is an increasing attention on human resource management. More specially, in universities, performance appraisal has been one of the new knowledge in this filed. Competency appraisal statistically and scientifically using psychological methods plays an important role on human resource performance measurement. For the first time, after the industrial revolution, performance appraisal of employee was performed, scientifically. In addition, during the last two decades, performance appraisal has experienced significant changes. First, the author concentration changed from a purely quantitative operation to a cognitive process. Second, researchers considered the effect of organizational and social structure on the evaluation and outcomes of appraisals.

Murphy \& Cleveland (1995) in their first book about performance appraisal showed that to appraise performance, we need a new model or a new approach. They believed that we could need a new model because of two reasons, during appraisal we do not show relationship between appraisal and scientific appraisal in related researches. Managers have comprehended that an organization can act successfully by considering efficiency and effectiveness. Therefore, in this field profit alone is one of the different scales of performance measurement.

The purpose of the most of the definitions of organizational performance is the capability to survive and an organization that is efficient but not effective cannot survive and act better than an organization that is effective. Therefore, most organizational theories expect to cover both efficiency and effectiveness (Campbell, 1970). Evaluation of organizations must go beyond of scientific techniques (Levinson, 1972). There are various methods to evaluate employee performance (Byers\& Rue, 2008) but recognizing which method is the best for organization depends on the purpose of organization, and usually to evaluate employee performance more than one method may be needed. Snell and Boulanger (2007) grouped performance appraisal methods as fallow:

- Methods based on personal characteristic such as: combined standard scale method, descriptive method, etc.

- Methods based on behavior or behavioral method such as: check list method, behavioral rank scale method, etc.

- Methods based on results such as: MBO method and BSC method.

Recently studies have shown good communication of managers with employee and listen and pay attention to employee suggestions can help them improve their performance significantly (Budd, 2010). This effect is significant especially when organizations follow their strategies and they are strategy-oriented organizations. Shuck (2011) stated that we must help employee participate in organization affairs as much as possible, he believed that this action help employee increase their performance. On the other way, work environment is considered as one of the key important and effective factors in improving performance and increasing employee participation (Busck, 2010).

Other effective factors like salary and having a performance appraisal system can improve employee performance too. In this study, we evaluate employee performance considering operational, practical and behavioral scales and to recognize effective factors on improvement of employee performance.

In this paper, we present an empirical study to measure the effect of various factors on performance of employees who worked for Islamic Azad University, South branch. This paper is organized as follows. We first present details of the proposed model in section 2. Next, we present details of our results and concluding remarks as well as possible suggestions are given at the end. 


\section{Method}

This research is an inductive one and the conceptual framework is as fallow:

\subsection{Procedure}

In terms of research process, to evaluate important issues in university, we interview with educational vice-president of school about quality of questionnaires. In this research, we used two types of questionnaires: The first one was used to evaluate scales of performance appraisal, which were common in related books and papers. These scales grouped in those parts: behavioral factors with 12 questions, operational factors with 9 questions and practical factors with 9 questions. The second one was used to evaluate effective factors on employee performance appraisal. Questions were 23 and 9 factors, performance based payment, salary, welfare service, working time, mutual relation of manager and employee, job pleasure, job security, performance appraisal system and job environment, were evaluated.
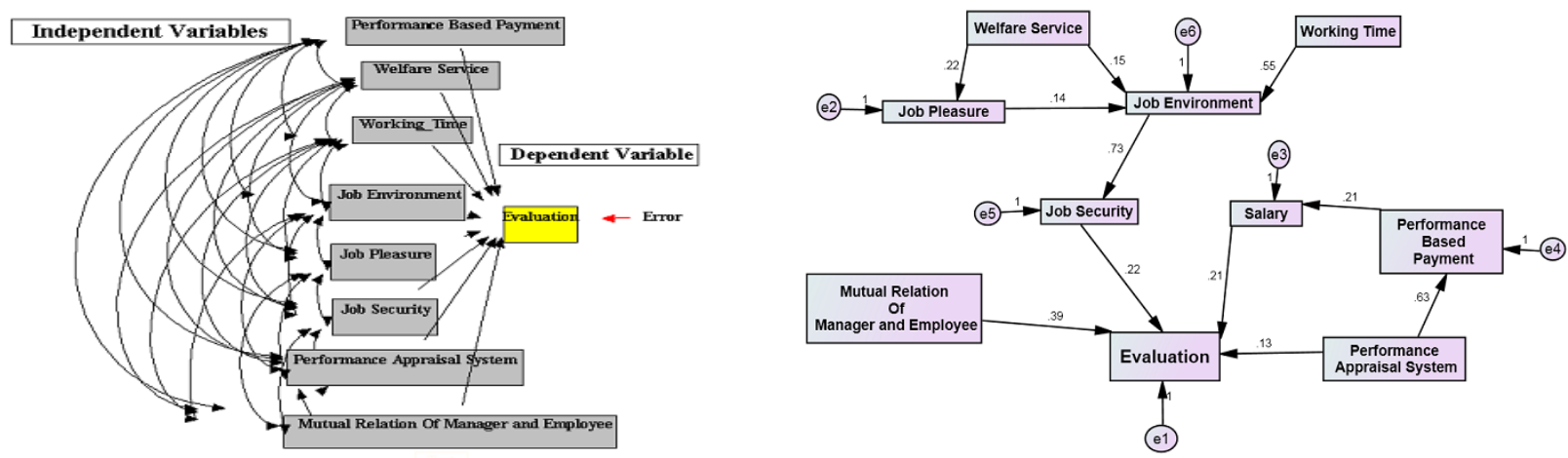

Fig. 1. The proposed framework of the study

In our survey, $51 \%$ of the participants were male while $49 \%$ of them were female, while the average age was 38. In terms of educational background, 39\% of the participants only finished high school, $50 \%$ hold bachelor degree and $11 \%$ of the participants hold PhD degree.

\subsection{Reliability}

Using SPSS software, reliability of questionnaires was measured using Cronbach alpha, it was equal to $99.4 \%$ for employee performance appraisal, and for the second one was 96.4 , which confirmed the overall survey.

\subsection{Statistical method}

In this research, we used Critical Path and Friedman Test methods to examine our hypothesis.

\subsection{Critical Path Method}

To test cause and effect models, mostly we used critical past method. We must draw a model as framework to evaluate the effect of any variables and to recognize to some extent this effect is direct and indirect. Using critical path method, we can gain simple information about cause and effect processes. Critical path is an expanded type of regression technique and usually uses multiple regressions to create cause-and-effect models. The purpose of critical path method is to extract important factors. Quantitative estimations of cause and effect have indicated the relations among some variables. Note that correlation data coming out of critical path method are just correlated and not necessarily cause and effect type. If two variables A and B are correlated with each other it is 
possible that a new variable, third one, influences both variables of $\mathrm{A}$ and $\mathrm{B}$. Therefore, cause and effect inference that is gained from correlation is named cause and effect modeling.

\subsection{Friedman Test}

This test is used to compare rank mean in different groups and is used to reveal whether these groups belong to one society or not. Scale in this test must be rank type. This test is nonparametric corresponding of $F$ test, and usually is used instead of $F$ test in rank scales. Friedman test is used to analysis two-way variance to compare rank mean of different groups.

\section{Findings}

Questionnaires 1 and 2 were distributed among all employees. The first questionnaire was distributed among managers for employee appraisal and the second questionnaire was distributed among employees for evaluation of effective factors on employee performance. 27 employees answered questionnaires 1 and 31 employees answered questionnaires 2. Considering mean mark of evaluation of any person, mean of society in study was gained 6.75 out of 10 . This shows that performance was high, most of frequencies were between 5 and 6.

Using questionnaire 2, we evaluated effective factors on performance where mean of factor for employee and manager's relationship was higher than other factors and standard deviation of factor of work hours was lower than other factors. In questionnaire 1 three main factors including behavioral, practical and operational ones were examined using 30 questions. Using Friedman test, we determined the rank of three main scales. Based on the results for freedman, behavioral, practical and operational ones were examined for 30 questions and mean rank for practically, behavioral and operational were 2.46, 2.02 and 1.52, respectively.

In questionnaire 2 that we evaluated the effect of 9 factors on performance, considering numbers and types of questions, to rank factors, we used Friedman test in SPSS software $\left(18^{\text {th }}\right.$ version). Rank of factors are summarized in Table 1 as follows,

\section{Table 1}

The results of Freedman test

\begin{tabular}{lc}
\hline \multicolumn{1}{c}{ Items } & Mean Rank \\
\hline Mutual Relation Of Manager and Employee & 8.18 \\
Performance Appraisal System & 6.17 \\
Performance Based Payment & 6.12 \\
Salary & 5.65 \\
Working Time & 4.57 \\
Job environment & 4.25 \\
Job Pleasure & 4.03 \\
Job Security & 3.75 \\
Welfare Service & 2.28 \\
\hline
\end{tabular}

Using conceptual framework of research, the manuscript of critical path model was entered to Amos 16 and considering amount error, the fallow model was gained, in this model some factors affect directly and some indirectly.

\section{Discussion and Conclusion}

Considering the results of evaluation in questionnaire 1, questions 22 and 24 that are practical ones, were gained the highest marks. In addition, two questions 5 and 17 associated with practical scale, question 5 related to behavioral scale gained the lowest mark. Considering the results of questionnaire 1 , it was revealed that in this school, employee performance in practical field was higher than 
expected, but in terms of operational and behavioral fields, they were in the middle stage. Therefore, they must be improved in these fields. Using Minitab15 software, with Pareto chart, we prioritized effective factors on employee performance. According to the results, the most important factor was recognized employee-manager relationships.

\section{Suggestions}

1. Improvement of operational and behavioral scale, especially factors of analysis and motivation must be considered.

2. According to critical path that we got from the Amos 16, relationships between managers and employees played essential role for improving performance. Therefore, we suggest that manager must improve their relationships with their employees.

In the next stage, improvement of job security and then increasing salary and at last payment based on performance appraisal system must be considered, seriously.

\section{Future Research}

1. Comparison of critical path results, methods of performance appraisal and performance improvement factors models, like Achieve are suggested.

2. It is possible to consider critical path using three main scale of evaluation instead of evaluation mark.

3. It is possible to perform a comparative comparison of employee appraisal in such a way that we used in this paper and 360 appraisals.

4. Finally, it is possible to use two dependent variables of performance appraisal and job satisfaction using critical path.

\section{Acknowledgement}

The authors would like to thanks the anonymous referees for their comments on earlier version of this paper.

\section{References}

Budd, J.W., Gollan, J.P., \& Wilkinson, A. (2010). New approaches to employee voice and participation in organizations. NJ: SAGE

Busck, O., Knudsen, H., \& Lind, J. (2010). The transformation of employee participation: Consequences for the work environment. NJ: SAGE

Byars, L.I., \& Rue, L.W. (2008). Human Resource Management: $9^{\text {th }}$ ed., New York: MGraw Hill.

Danaei, A \& Hosseini, A. (2013). Performance measurement using balanced scorecard: A case study of pipe industry. Management Science Letters, 3(5), 1433-1438.

Kohneh, A., Yazdani, B \& Kamalian, A. (2013). Performance measurement in governmental agencies using BSC-AHP: A case study of Civil Registry Office in Tehran. Management Science Letters, 3(4), 1255-1260.

Levinson, H., Molinari, J., \& Spohn, A. G. (1972). Organizational diagnosis (pp. 223-24). Cambridge, MA: Harvard University Press.

Mozaffari, A., Karkehabadi, H., Kheyrkhahan, M \& Karami, M. (2012). A development in balanced scorecard by designing a fuzzy and nonlinear Algorithm (case study: Islamic Azad university of Semnan). Management Science Letters , 2(5), 1819-1838.

Mozaffari, A., Kalaei, H., Shahhosseini, M \& Chaghouee, Y. (2013). A new framework for performance evaluation system using strategy map: A case study of Islamic Azad University of Semnan. Management Science Letters , 3(4), 1041-1048. 
Murphy, K. R. \& Cleveland, J. (1995). Understanding Performance Appraisal: Social, Organizational, and Goal-based Perspectives, NJ: SAGE

Murphy, K. R. (2008). Explaining the weak relationship between job performance and ratings of the job performance. Industrial and Organizational Psychology, 1 (2), 148-160.

Sekaran, U. (2010). Research Methods for Business: A Skill Building Approach, 5th ed. John Wiley \& Sons Ltd.

Shuck, B.(2011). Four Emerging Perspectives of Employee Engagement: An Integrative Literature Review. NJ: SAGE

Snell, S. A \& Bohlander, G. W. (2007). Managing Human Resources. Thomson Publishing Company.

Soo, S \& Lewis, G. B. (2009). Can Performance Appraisal Systems Inspire Intrinsically Motivated Employees? NJ: SAGE 